\title{
Implementation of International Legal Norms by the Russian Federation in the Field of Protection and Preservation of the Marine Environment from Pollution
}

\author{
Ksenia B. Valiullina, Gennadiy I. Kurdukov \\ Kazan Federal University, 18 Kremlevskaya Street, Kazan, Russia, 420008 \\ Email: ksenia801@list.ru, Contact: 89179329750
}

Received: 15th December 2017, Accepted: 20th December 2017, Published: 31st December 2017

\begin{abstract}
Historically, the Russian Federation is the leading sea power that is defined by its territorial and geophysical features, existence of exits to three oceans uniting 14 seas, the greatest opening of the Russian seafarers and travelers, and, certainly, an essential contribution to studying of the World Ocean at the present stage. Activity of the Russian Federation in the sphere of protection of the marine environment, is directed to application not only standards of the national right, but also the relevant provisions of international treaties. The constitution of the Russian Federation recognized the conventional principles and rules of international law, and also the international contracts as components of legal system of the Russian Federation, the aspiration to cooperate on the most important questions of providing global environmental problems where protection and preservation of the marine environment acts as one of priority activities, taking into account rapid economic and technological growth, on the basis of understanding of as a part of the world community thereby was expressed. Despite existence throughout a long time of not ecological approach in all directions of economic activity of the states, today, all efforts are bent on introduction of "green" economy which main lines are: reduction of emissions of dangerous pollutants in the atmosphere and in water objects, rational use of natural objects and live resources, use of technologies of renewables, protection and preservation of a biodiversity, improvement of quality of life of people, along with improvement of a condition of all components of the surrounding environment. In article the ecological situation in the Russian Federation in relation to a question of ensuring protection and preservation of the marine environment is analyzed; on the example of the Convention of the UN on marine law of 1982 which is the fundamental document in the field of protection of the marine environment problems of implementation of rules of international law in the Russian legal system, recognition of the main international legal norms by a part of the internal law of Russia, and also validity of the international acts in the field of protection of the marine environment in the territory of the country are investigated.
\end{abstract}

Keywords: Marine Environment, Russian Federation, Protection and Preservation, Implementation, Cooperation of the States, Prevention of Pollution.

\section{Introduction}

"The nature is also that source of beauty which gets on all, from which everyone scoops in process of understanding"

Timiryazev K. A.

For the last thirty years of water of the World Ocean are used so intensively that the problem of ensuring its protection and preservation is among new calls and threats in the international marine law. Special attention of the world community to this international legal problem is caused first of all by the fact that the World Ocean represents the complete system influencing, directly, climate of all planet, a plant and animal life, and also processes of activity of the person. Welfare of present and future generations depends on its state, ability to restoration. The ocean, is the huge tank, the main supplier of energy, oxygen of the planet, valuable protein, nevertheless, daily from all possible sources tons of toxic agents, sewage, oil and oil products, chemical, biological, radioactive and other poisoning and destroying materials and connections get to the seas and oceans. As a result, today, many regions of the World Ocean lost ability to selfcleaning. [1]

Protection of the marine environment represents system of the legal relationship demanding the coordinated actions of international law and the national legislation. Joining this or that convention, the states, thereby, undertake an obligation for implementation of the relevant provisions in the national legislation. [2] Standards of the international and national law have to work in unity, for the purpose of compliance to natural developments of activity in the World Ocean and to interests of the states. It, certainly, does not mean, full following to all provisions, passing at the same time national interests, interests of society of the relevant state. The principle of sovereign equality of the states defines their right of independent definition the place of international legal norms in the legal system. Nevertheless, combination of efforts of this sort of the international and national law is directed, first of all, to increase in the standard of living of the person and the nature. For successful 
realization of international legal norms in the field of protection of the marine environment at the national level, it has to be provided a possibility of change or full cancellation by the states of the provisions contradicting international legal norms and also sending on use of the relevant standards which in turn, will govern the relations within the country.

Because of increase in integration processes in Europe and in Russia which takes place in the last decades the question of influence of international law on the national legislation is especially urgent. Interest in a problem of implementation is explained also by ambiguity of approaches to a question of recognition of international legal norms and provisions of international treaties a part of legal system of Russia. The concept "implementation" (from English implementation-the actual realization) in the Russian legal science is used without the translation and means implementation at the interstate level of the international obligations and introduction of standards of international legal character in national legal system of the state. [3] The studied perspective has all-legal character and has extremely important value in the sphere of permission of the major questions concerning the rights and freedoms of the person, ensuring ecological safety, prevention of military operations, radioactive infection and other questions on which peaceful and safe existence of the person and the environment depends. [4]

\section{Methods}

As a methodological basis of a research the method of the system and structural analysis which helps to disclose importance of a question of ensuring protection of the World Ocean from pollution in relation to the Russian Federation is used. For modern interpretation of provisions of the Russian legislation and the international conventional standards the combination of methods of historical and political science, the international legal analysis was applied. Special scientific methods were applied to the solution of research tasks, along with general scientific: formal and logical, comparative jurisprudence, legal modeling, and also logical receptions, such, as: induction and deduction, generalization and comparison.

\section{Results and Discussions}

Russia historically is the great sea power having the largest fleet, an exclusive stock of fuel and energy resources, in particular, the largest oil fields, natural gas, coal, nickel etc. It is known that security with natural resources, their sizes, structure and stocks I determine the level of economic and political development of society and, at the same time, can guarantee economic development only if their operation is carried out according to the principle of rationality, with respect for the international and national standards ensuring their safety. Activity of the Russian Federation in the sphere of protection of the marine environment, is directed to application not only standards of the national right, but also the relevant provisions of international treaties. The constitution of the Russian Federation recognized the conventional principles and rules of international law, and also the international contracts as components of legal system of the Russian Federation. In case of contradictions between national norms and the international treaty, rules of the last are applied. [5] Existence of the specified precept of law, expressed the aspiration to cooperate on the most important questions of providing global environmental problems taking into account rapid economic and technological growth, on the basis of understanding of as a part of the world community. Russia recognizes need of the international cooperation on all directions in the field of protection and preservation of the marine environment, recognizing that having only combined efforts of all countries, it is possible to provide protection of the World Ocean showing universal property. The constitution of the Russian Federation allows providing openness of the interstate system to international law which admits the directing reference point of internal standard and legal development. [6] The federal law of July 15, 1995 "About international treaties of the Russian Federation" gives to No. 101-FZ the detailed description of the provisions enshrined in the Constitution, indicating that the international contracts of the Russian Federation are a part of its legal system, and are subject to application in all territory of the country, at observance of the conditions of their applicability established by the Russian legislation, and in case of the conflict between the international contractual standards and the domestic legislation of the Russian Federation contracts have a priority before the law. [7]

In the sphere of ensuring protection and preservation of the marine environment in legal system of Russia it is expedient to carry out degree of the importance and feasibility of international treaties in the analysis of operation of the Convention of the UN on marine law of 1982, its compliance to the application conditions established for the international treaties existing in the territory of the country. So, the Russian Federation ratified the Convention of the UN on marine law signed to Montego Bay on December 1, 1982 [8] and also the Agreement on implementation of part XI of the Convention of July 29, 1994 [9], the Federal law of February 26, 1997 No. 30-FZ "About ratification of the Convention of the United Nations on marine law and Agreements on implementation of part XI of the Convention of the United Nations on marine law", thereby having 
undertaken the obligation for observance of all conventional provisions aimed at providing protection and preservation of the marine environment except for the reservation made in full compliance with Art. 298, 309 and 310 of the Convention according to which Russia once again showed the aspiration to work within international legal norms.

According to provisions of the Vienna Convention on the right of international treaties [10], the consent of the states to adoption of terms of the contract and obligation of its action in legal system of the countries has to be expressed in the form of ratification, in that case if its need is confirmed with the corresponding international treaty. The requirement for ratification contains in Art. 306 of the Convention which the Russian Federation successfully executed adoption in 1996 of the Federal Law "About Ratifications of the Convention of the United Nations on Marine Law and the Agreement on Implementation of Part XI of the Convention of the United Nations on Marine Law". The following necessary condition, according to the Vienna convention, is official adoption, the introduction of the international treaty in force which was also executed by the Russian Federation on November 16, 1994. The text of the Convention, according to the Federal Law "About International Treaties of the Russian Federation" No. 101FZ was published of 15.07.1995 in the Collection of the Legislation of the Russian Federation [11].

As it was enshrined in the Constitution of the Russian Federation, standards of international treaties are a component of legal system of Russia and have a priority over domestic laws. Nevertheless, one of features of the Convention is that it contains norms which are self-executable, have direct application of "direct applicability" [12], and, therefore, do not assume adoption of the relevant normative legal acts, and a number of provisions which for successful realization, demand settlement at national interstate level. It is connected, first of all, with the fact that conventional norms are directed to fixing of the rights and duties of the State Parties and all world community in questions of protection and preservation of the marine environment, strengthening of cooperation between them for ensuring the rational, sparing approach to operation of waters and resources of the World Ocean. Respectively, the citizens and legal entities who are living and carrying out economic activity in the territory of member countries are not direct carriers of all rights and duties established by the Convention and consequently ensuring their regulation is carried out in the course of implementation of international legal norms in the domestic legislation of the countries.

\section{Summary.}

Signing of the Convention of the UN on marine law of 1982, the Russian Federation expressed the consent to acceptance of all possible measures at the international and national level for ensuring protection of all components of the environment where protection and preservation of the marine environment is the priority direction. Realizing need acceptance of drastic measures on prevention of further degradation of the World Ocean and compliance to conventional norms, in Russia, at all levels, work on providing the consecutive stage-bystage solution of problems of ecologically sustainable development for the period to 2030 and is conducted the next years.

A number of provisions the Convention of the UN of 1982 found reflection in the national legislation of the Russian Federation. The special norms concerning protection and preservation of internal waters and territorial sea which by the Russian legislation belong to objects of the water relations are regulated according to the Water code of the Russian Federation adopted in 2006. Provisions of the Convention found fixing in laws of the Russian Federation, namely: Federal Law "About Internal Sea Waters, the Territorial Sea and a Contiguous Zone of the Russian Federation" of 1998, Federal Law "About the Continental Shelf of the Russian Federation" of 1998, Federal Law "About an Exclusive Economic Zone of the Russian Federation" of 1998; The Federal Law of January 9, 1996 No. 3-FZ "About radiation safety of the population"; The Federal Law of May 2, 1997. "About destruction of chemical weapon" (with amendment and additional) The Federal Law of July 11, 2011 N 190-FZ "About the treatment of radioactive waste and about introduction of amendments to separate acts of the Russian Federation" and many others. All specified normative legal acts contain provisions the concerning aspirations of the Russian Federation to take active steps concerning ensuring environmental protection, and also protection and preservation of the marine environment from pollution.

In January, 2016 the President of the Russian Federation Vladimir Putin signed the decree according to which 2017 was announced year of ecology. As main objectives of the specified decision it was noted: increase in attention to environmental problems in the Russian Federation; improvement of a condition of an ecological situation in the country; introduction to all spheres of life of society of nature protection technologies and, as a result, increase in ecological indicators of regions of the country; development of modern, ecologically safe methods of recycling; protection and protection of water, 
forest, land and air systems. In relation to the marine environment, the Decree of the Russian President approved the Sea doctrine of the Russian Federation for the period till 2020 which legal basis was made by the Constitution of the Russian Federation, federal laws and other regulations of the Russian Federation, the Convention of the UN on marine law of 1982, the international contracts in the field of sea activity, use of resources and the world ocean. [13] The order of the Government of the Russian Federation of December 8, 2010 approved the Strategy of development of sea activity of the Russian Federation till 2030 which is aimed at providing interests of the Russian Federation in the World Ocean, the Federal target program "Clear water" for 2011-2017, and also the "Development of a Water Management Complex of the Russian Federation in 2012-2020" Program is approved. In 1997 the Decree of the President of the Russian Federation approved the concept of the federal target program "World Ocean". It is specified in it that one of priorities of the international interests of Russia in the World Ocean is protection and preservation of the marine environment taking into account the international obligations. "Today, - the president of the Russian Federation V. V. Putin fairly notes, - the conversation on environmental problems should be carried on in an offensive and practical key and to bring nature protection work to the level of a system, daily duty of the government of all levels". [14] In this regard, in December, 2012 the order About the approval of the state program of the Russian Federation "Environmental protection" for 20122020 where realization of a complex of the nature protection actions directed to increase in level of ecological safety, ensuring preservation and restoration of natural objects of Russia is offered was published. In recent years in the Russian Federation the course towards realization of an initiative "Green economy" which, in 2008 began to be carried out by the United Nations was accepted, and in 2012 it was included in the agenda "Rio +20 " as the main tool for achievement of sustainable development. [15] Continues to take place and vigorous activity of the Russian Federation in the sphere of development of cooperation in preservation of the marine environment both within multilateral conventions, and at the level the agreement on a bilateral basis with the CIS countries, the FSU and beyond, active participation in the relations of improvement of quality of functioning of a number of the international and regional Conventions is carried out. Globalization promotes mass revision of the main directions by the states in policy and economy. Russia in this regard is not an exception, and despite a set of unresolved problems, it is possible to speak about essential and significant steps in improvement of an ecological state in the Russian Federation already today.

\section{Conclusion}

Summing up the results of told, it is possible to formulate a conclusion that in the Russian Federation provisions of the Convention of the UN on marine law of 1982 which is the main document in the field of ensuring protection and preservation of the marine environment from pollution are implemented fully both due to direct action of conventional norms, and by means of the publication of the interstate acts obligatory for performance of the internal law of the country by all subjects. Therefore, the Convention as it is told in the Constitution of the Russian Federation has direct action in the territory of the country, and its norms are subject to application by all law-enforcement bodies of the Russian state.

\section{Acknowledgement}

The work is performed according to the Russian Government Program of Competitive Growth of Kazan Federal University.

\section{References}

[1] Valiullina K.B., Khodzhiyev A.R. State cooperation in matters of ensuring protection and preservation of the world ocean/The Turkish Online Journal of Design, Art and Communication/TOJDAC/November/2016/Special Edition/

[2] Sokolova N. A. Interaction of the international and internal law in the sphere of environmental protection//the Siberian legal messenger / Yurid. Ying - $t$ to the YOKE. 2001. No.3.

[3] Cambridge dictionary. Implementation/available at:

$\leq$ http://dictionary.cambridge.org/dictionary/english/ implementation>

[4] N. V. Minina. Problems of implementation of rules of international law in the Russian VI Ministry of Internal Affairs legal system//Messenger of Russia. 2011. No. 4

[5] Constitution of the Russian Federation. M, 1993. - Page 9.

[6] D.A.Gavrilin. About the status of the Convention of the UN on marine law of 1982 in the legal Russian Federation system. TISBI bulletin. - 2001. - No.4

[7] Collection of the legislation of the Russian Federation.-1995. - No. 29. - Art. 2757

[8] United Nations Convention on the Law of the Sea 1982.

[website]

<http://www.un.org/depts/los/convention_agreemen ts/texts/unclos/unclos_e $>$ 
[9] Agreement Relating to the Implementation of Part XI of the United Nations Convention on the Law of the Sea. <http://lawin.org/agreementrelating-to-the-implementation-of-part-xi-of-theunited-nations-convention-on-the-law-of-the-sea/>

[10] Vienna Convention on the Law of Treaties 1969. Done at Vienna on 23 May 1969. Entered into force on 27 January 1980. United Nations, Treaty Series, vol. 1155 , p. 331

[11] The convention of the UN on marine law of December 10, 1982//the Collection of the legislation of the Russian Federation. - 1997. - No. 48. - Art. 5493.

[12] I. Brownlie. Principles of Public International Law. 5th ed. Oxford: Clarendon Press. 1998.
[13] The sea doctrine of the Russian Federation for the period till 2020. It is approved by the Decree of the President of the Russian Federation of July 27, 2001. [website] http://docs.cntd.ru/document/902010411

[14] The order of December 27202 years No. 2552$r$ About the approval of the state program of the Russian Federation "Environmental protection" for 2012-2020. [website] of http://m.government.ru/docs/3350/

[15] United Nations Environment Programme. Green Economy. [available at https://www.unep.org/greeneconomy/] 